\title{
New pieces in the transmission cycle of the hepatitis E virus in South America: first viral detection in wild boars from Argentina
}

\author{
María Belén Pisano $^{a, *}$, Marina Winter ${ }^{b}$, Natalia Raimondoc, Maribel G. Martínez-Wassaf ${ }^{c}$, Sergio D. Abate ${ }^{b}$ \\ and Viviana E. Réa
}

\begin{abstract}
${ }^{a}$ Instituto de Virología 'Dr. J. M. Vanella', Facultad de Ciencias Médicas, CONICET, Universidad Nacional de Córdoba, Enfermera Gordillo Gómez s/n, Ciudad Universitaria, X5016, Córdoba, Argentina; ${ }^{b}$ Centro de Investigaciones y Transferencia, Universidad Nacional de Río Negro-CONICET, Sede Atlántica, Viedma, R8500, Río Negro, Argentina; 'Laboratorio de Virología y biología molecular, LACE. Av. Vélez Sársfield 528, X5000JJS, Córdoba, Argentina
\end{abstract}

*Corresponding author: Enfermera Gordillo Gómez s/n, X5016, Córdoba, Argentina. Tel: +54-351-4334022; E-mail: mbelenpisano@gmail.com

Received 15 January 2019; revised 26 March 2019; editorial decision 8 April 2019; accepted 8 April 2019

Background: The hepatitis E virus (HEV) causes hepatitis worldwide. In Europe, wild boars are known to be viral reservoirs and sources of infection. In South America, there is a lack of information about HEV in these animals.

Methods: A total of 102 wild boar serum samples from Argentina (2014-2017) were studied for serological and molecular HEV detection.

Results: We obtained a seroprevalence of $19.6 \%$, similar to that recently described in Uruguay (the only antecedent in South America). HEV ribonucleic acid (RNA) was amplified in two anti-HEV-positive samples.

Conclusions: This is the first report of HEV circulation in wild boars from Argentina, adding evidence to the findings obtained in Uruguay indicating that wild boars could be viral reservoirs in South America.

Keywords: Argentina, hepatitis E virus, wild boars

\section{Introduction}

The hepatitis E virus (HEV; family Hepeviridae, genus Orthohepevirus, species Orthohepevirus A) is an important pathogen of worldwide distribution and a public health problem in endemic countries, causing epidemic outbreaks. In recent years, sporadic acute cases have been reported in industrialized countries and/or non-endemic regions. ${ }^{1}$ Of the eight described genotypes, genotypes 3 (HEV-3) and 4 (HEV-4) are zoonotic viruses that infect humans by direct contact or ingestion of contaminated meat products derived from pigs, wild boars and deer. $^{1,2}$

In Latin America, circulation of HEV-3 in pig herds has been confirmed and phylogenetic analysis has shown a high degree of relatedness among human and swine strains in many regions. However, the role of wild boars (Sus scrofa) in the transmission of HEV has not been studied in depth. ${ }^{3}$ Mirazo et al. ${ }^{4}$ reported for the first time on the continent, the presence of HEV in wild boars from Uruguay, pointing to these animals as possible reservoirs and sources of infection in the Americas.
In Argentina, HEV causes sporadic acute cases of hepatitis and has been reported to be the aetiological agent of two chronic cases. Also, this virus has been detected in pigs and environmental waters in Argentina, ${ }^{3}$ which could be possible sources of the virus. Since there are no investigations about HEV in wild boars in our region, and to expand the knowledge in South America, we aimed to investigate the circulation of HEV in wild boars from Argentina, performing serological and molecular detection.

\section{Materials and methods}

\section{Samples and studied area}

A total of 102 serum samples from wild boars, collected in the northeast area of the Patagonia region of Argentina (Figure 1) between August 2014 and August 2017, were analysed for antiHEV antibody detection and HEV ribonucleic acid (RNA) amplification.

Blood samples were taken from animals captured by authorized hunters (Law 5786, decree 2578-1403/05, resolution 25, for Buenos Aires province; Law 2056, decree 633/86, resolution

(c) The Author(s) 2019. Published by Oxford University Press on behalf of Royal Society of Tropical Medicine and Hygiene. All rights reserved. For permissions, please e-mail: journals.permissions@oup.com. 


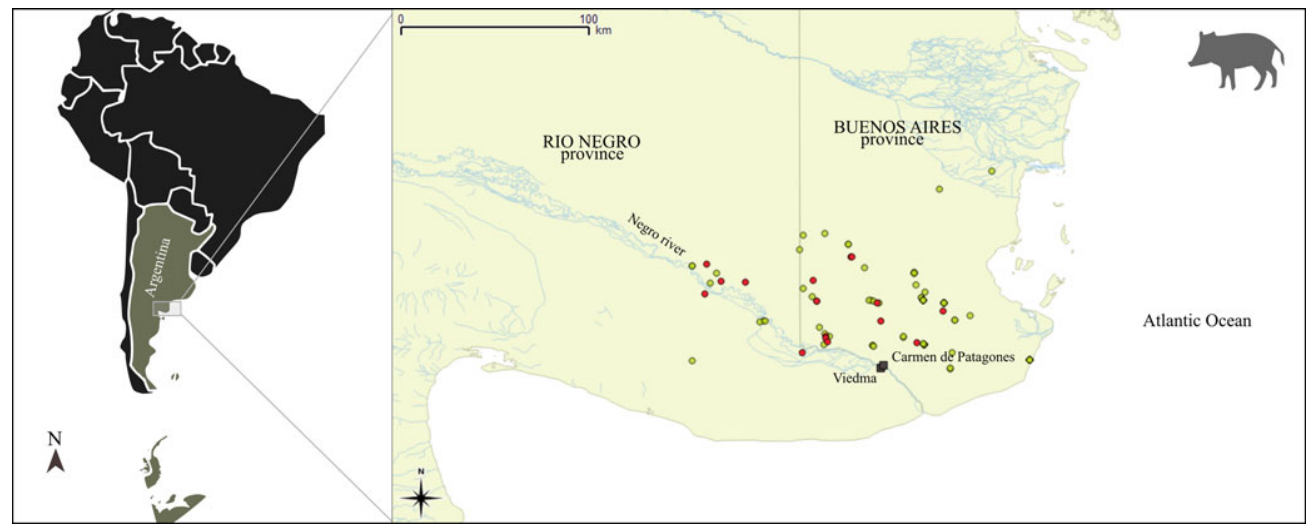

Figure 1. Map showing the area in Argentina where the wild boar serum samples were collected. Red dots correspond to the positive anti-HEV samples while yellow dots correspond to the negative anti-HEV samples.

236, for Río Negro province) during hunting seasons, following local requirements for descriptive studies. Most of the study areas are private fields, where the native vegetation alternates with semi-intensive livestock (bovine, ovine and porcine) and farming production. Free-range wild boars move among the fields mainly at night; during the day they take refuge in the shrubby vegetation. Sometimes it is possible to observe male wild boars in contact with female domestic pigs.

\section{Serological test}

Total anti-HEV antibodies were tested in the serum samples by enzyme-linked immunosorbent assay (HEV Ab Ultra; Dia.Pro, Milan Italy).

\section{Molecular detection}

Serologically positive samples were subjected to HEV RNA amplification by nested reverse transcription polymerase chain reaction (PCR) targeting the ORF2 region. ${ }^{5}$ The retrotranscription was carried out using the enzyme Improm II (Promega, Madison, WI, USA) and random hexamer primers. For the amplification, the enzyme GoTaq (Promega) was used, following the manufacturer's instructions. Amplicons obtained were submitted to direct sequencing (Macrogen, Seoul, Korea).

\section{Results}

From the 102 serum samples analysed, 20 were positive for anti-HEV antibody, obtaining a seropositivity of $19.6 \%$. This was similar to that found in Uruguay $(22.1 \%)^{4}$ and comparable to that observed in high-income European countries, where the role of wild boars as viral reservoirs is known. ${ }^{6}$ The distribution pattern of the positive samples was homogeneous (Figure 1), showing the absence of an area with more viral circulation. Molecular amplification could be performed in two of the samples that were positive by serological tests. Sequences could not be obtained, as the resulting bands were very faint. This was also observed in the previous Uruguayan study, in which positive molecular results from wild boar serum samples were obtained but it was not possible to amplify the RNA by conventional PCR or sequence them. ${ }^{4}$ The low viral load in serum samples, as well as the short viraemia, are reasons that may explain the inability to obtain sequences. Further studies on HEV RNA detection in wild boar liver and stool samples could be performed to achieve HEV sequences for the region.

This is the first investigation of HEV in wild boars from Argentina, and the second for Latin America, showing evidence of HEV circulation in these animals. S. scrofa is currently distributed throughout Argentina ${ }^{7}$ as a consequence of their introduction by Spanish settlers, ${ }^{8}$ and later, around 1906 (Eurasian wild boars), ${ }^{7}$ for hunting purposes. They are a problem not only for the native flora and fauna, but also as a possible reservoir and source of infection for HEV. The absence of geographic barriers in some regions has led to border crossing events and the spread of these animals and, as a consequence, the spread of the HEV.

Wild boars are gaining importance in the region due to an increase in the consumption of their meat as an alternative to the traditional meats marketed in Argentina (beef and chicken). Wild boar meat is obtained from farms (of which there are very few) and from hunting (the main source of this type of meat in Argentina) and then sold commercially for its consumption or for the production of its derivatives, such as sausages and pates, with the highest production in the south of Argentina. ${ }^{9}$

Our findings show the need for more studies focused on the investigation of HEV in wild boar liver, meat and derivatives, as well as expanding research to more regions, which will help to determine the role of these animals in the HEV cycle in Argentina and the continent.

Author's contributions: MBP designed the study, performed the molecular analysis, analysed the results and wrote the original manuscript. MW and SDA collected the samples and provided wild boar information. NR and MGMW performed the serological analysis. VER designed the study, supervised the analysis and approved the final version of the manuscript. All authors contributed to the writing and correcting of the draft manuscript. 
Acknowledgements: None.

Funding: This work was supported by the Agencia Nacional de Promoción de Ciencia y Técnica de Argentina (ANPCyT, Foncyt) (grants PICT 2014-2537 and PICT 2016-2165).

Competing interests: None declared.

Ethical approval: Samples were taken according to Argentine requirements for descriptive studies. Blood samples were taken from animals captured by authorized hunters during hunting seasons (Law 5786, decree 2578-1403/05, resolution 25, for Buenos Aires province; Law 2056, decree 633/86, resolution 236, for Río Negro province).

\section{References}

1 Hoofnagle JH, Nelson KE, Purcell RH. Hepatitis E. N Engl J Med. 2012; 367(13):1237-44.

2 Smith DB, Simmonds P, Izopet J, et al. Proposed reference sequences for hepatitis E virus subtypes. J Gen Virol. 2016;97(3):537-42.
3 Pisano MB, Martinez-Wassaf MG, Mirazo S, et al. Hepatitis E virus in South America: the current scenario. Liver Int. 2018;38(9):1536-46.

4 Mirazo S, Gardinali NR, D’Albora C, et al. Serological and virological survey of hepatitis $\mathrm{E}$ virus (HEV) in animal reservoirs from Uruguay reveals elevated prevalences and a very close phylogenetic relationship between swine and human strains. Vet Microbiol. 2018;213: 21-7.

5 Huang FF, Haqshenas G, Guenette DK, et al. Detection by reverse transcription-PCR and genetic characterization of field isolates of swine hepatitis $E$ virus from pigs in different geographic regions of the United States. J Clin Microbiol. 2002;40(4):1326-32.

6 Clemente-Casares P, Ramos-Romero C, Ramirez-Gonzalez E, et al. Hepatitis $E$ virus in industrialized countries: the silent threat. Biomed Res Int. 2016;2016:9838041.

7 Novillo A, Ojeda RA. The exotic mammals of Argentina. Biol Invasions. 2008;10(8):1333-44.

8 Crosby AW. Ecological imperialism: the biological expansion of Europe, 900-1900. New York: Cambridge University Press; 1986, p. 368.

9 National Ministry of Agriculture and Industry of Argentina. Ficha №56: Incluí carne de jabalí en tu alimentación. 2016. https://www. argentina.gob.ar/agroindustria. 